\title{
Diaspora Politik Keluarga Organisasi Nahdlatul Wathan pada Pemilu Legislatif 2014 di Lombok, Nusa Tenggara Barat
}

\section{FAHRURROZI}

Universitas Islam Negeri Mataram roziqi_iain@yahoo.co.id.

\section{ABSTRACT}

This article confirms that the decision of Nahdlatul Wathan organization not to engage in the field of practical politics cannot be separated from the fact that a number of the organization's members do the opposite. Hence, such contradiction may lead to a conflict of interest between the organization's missions, which are to solely focus on three main domains of activities: education, social transformation, and dakwah islamiyah, with a number of practically engaging members in politics who may take advantage of their Nahdlatul Wathan organizational position to raise voters. Apart from their mission statement, Nahdlatul Wathan always takes a strategic position in the political culture of West Nusa Tenggara. This can be observed from three aspects: (1) the supported political party, (2) the owned social capital and (3) the massive organization's role. Based on these three aspects, the Nahdlatul Wathan and a number of its members always participate in assuming legislative and executive powers.

Keywords: politics, contestation, diaspora, Nahdhatul Wathan

\section{ABSTRAK}

Artikel ini menegaskan tentang pilihan organisasi Nahdlatul Wathan untuk tidak berpolitik praktis memang tidak bisa dipisahkan dengan pilihan keluarga besar Nahdlatul Wathan yang terjun ke dunia politik praktis. Sedikit tidak akan bias antara khittah organisasi dengan kepentingan keluarga besar Nahdlatul Wathan yang bisa memanfaatkan organisasi Nahdlatul Wathan menjadi tunggangan politik meraih kekuasaan, terlepas dari apapun motivasinya di mana Nahdlatul Wathan sebagai organisasi keagamaan menegaskan dirinya hanya bergerak pada tiga domain utama; pendidikan, sosial, dan dakwah islamiyah. Meskipun demikian, Nahdlatul Wathan selalu mengambil posisi yang strategis 
dalam kancah perpolitikan di NTB. Hal ini terlihat dalam beberapa aspek: Pertama: aspek partai politik yang didukungnya, kedua: aspek modal sosial yang dimilikinya dan ketiga aspek peranan organisasi yang massif. Ketiga aspek tersebutlah, Nahdlatul Wathan dan keluarga besar Nahdlatul Wathan selalu ikut berpartisipasi dalam merebut kekuasaan melalui lembaga eksekutif maupun legislatif.

Kata Kunci: politik, kontestasi, diaspora, Nahdhatul Wathan.

\section{PENDAHULUAN}

Kekuasaan dan pelestarian dinasti keluarga dapat terbentuk secara melembaga dan secara kultur dengan mengedepankan teori Daniel Fitzpatrick tentang diaspora politik dinasti yang didasarkan pada pembentukan preferensi politik familisme yaitu faktor afeksional, seperti kepercayaan (trust), solidaritas (solidarity) maupun soliditas (solidity) yang secara keseluruhan turut menentukan eksistensi dinasti politik, baik antara anggota internal keluarga maupun kroni-kroni yang berada dalam lingkar kekuasaannya. ${ }^{1}$

Secara umum, basis fondasi kekuasaan formal dinasti politik lokal di Indonesia dibangun berdasarkan hubungan paternalistik melalui redistribusi program populis yang dihasilkan melalui skema politik 'gentong babi' (pork barrel politics) maupun politisasi siklus anggaran (politic budget cycle). Hal itulah yang kemudian mendorong adanya hubungan kedekatan maupun romantisme antara pemimpin dengan rakyatnya sehingga pemimpin mudah dalam membentuk politik persuasif melalui gelontoran uang hingga ke pelosok. ${ }^{2}$

Berkaitan dengan suksesi kepemimpinan, politisasi birokrat maupun sosialisasi tokoh informal masyarakat menjadi bagian intimitas yang bertindak sebagai agen intermediasi dalam memenangkan dan melanggengkan kekuasaan family politik. Perbincangan mengenai dinasti politik dalam ranah politik lokal sangatlah berbeda dengan konteks dinasti politik yang terjadi di level nasional. Dalam ranah lokal, romantisasi nama besar familisime menjamin suatu dinasti politik dapat eksis secara terus-menerus. ${ }^{3}$

Familisme sendiri dibentuk atas tiga hal, yakni figur (personalism), klientelisme (clientelism), dan tribalisme (tribalism), sebagai ketiga kunci dalam mengurai basis-basis terbentuknya tren familisme kekuasaan dalam demokrasi lokal di Indonesia. Ketiga proses tersebut berperan besar dalam suksesi pemerintahan lokal di Indonesia yang dilakukan dalam dua jenis yakni secara by design dan by accident. Dinasti politik yang by design 
sudah terbentuk sejak lama dimana jejaring familisme dalam pemerintahan sendiri sudah kuat relasionalnya sehingga kerabat yang ingin memasuki kancah pemerintahan maupun politik sudah didesain sejak awal untuk menempati pos tertentu. Adapun by accident sendiri terjadi dalam situasi suksesi pemerintahan yang secara tiba-tiba mencalonkan kerabat untuk menggantikannya demi menjaga kekuasaan "informal" terhadap penggantinya kelak jika memang dalam Pemilukada.

Dalam mayoritas kasus Pemilukada di Indonesia sendiri termasuk di Lombok-NTB, suksesi kekuasaan berbasis familisme ada yang dilakukan secara by accident maupun by design di NTB. Model by design yang dominan adalah istri yang maju menggantikan suami atau anak menggantikan bapaknya. Sementara itu, model by accident adalah kerabat sebagai calon kepala daerah hanya sebagai bayangan atas kerabat lain yang difavoritkan akan memenangkan Pemilukada.

Pola pengajuan kandidat tersebut biasanya dilakukan secara sporadis untuk menghalangi calon lain maju dalam proses pengajuan kandidat. Dapat dikatakan bahwa intimitas hubungan keluarga kemudian menjadi platform politik guna mengamankan kekuasaan daerah. Pola suksesi aksidental dalam model dinasti politik seperti ini kerap kali memunculkan anekdot kuasa gono-gini ataupun 'arisan kekuasaan' karena transisi kekuasaan daerah hanya terjadi di dalam satu rumah saja. Selain itu, tren familisme dalam dinasti politik aksidental seperti ini tidak akan bertahan lama. Hal ini karena regenerasi kekuasaan tidak dilakukan secara matang, melainkan hanya mengejar pragmatisme politik belaka.

Secara garis besar, konteks budaya politik familisme yang berlangsung dalam ranah politik lokal lebih mengarah pada proses figurisasi sebagai daya tarik pemilih yang kemudian dikomodifikasi menjadi dasar politis seseorang untuk menarik kerabatnya dalam lingkaran kekuasaan. Dalam hal ini, perspektif budaya politik familisme sudah mengafirmasi berbagai gejala umum yang berkembang dalam mendasari dinasti politik. Faktor intim, seperti kepercayaan maupun solidaritas masih ada dan berkembang hingga membentuk pemerintahan dinasti.

\section{SETTING SOSIAL POLITIK DI NTB}

Mencermati perubahan arah perpolitikan masyarakat NTB, khususnya Organisasi NW, dapat dilihat dari awal mula kontaknya TGKH M. Zainuddin AM ke dunia politik, sebab pada saat itu sosok dialah yang paling 
berpengaruh dalam mempolarisasi perpolitikan masyarakat Sasak. Maka dalam konteks ini perlu dibaca ulang perpolitikan TGKH M. Zainiddin Abdul Majid sebagai landasan awal untuk melihat paradigma sosio-politik masyarakat NW. ${ }^{4}$

Karier politik TGKH M. Zainuddin Abdul Madjid dimulai sejak ia diangkat menjadi Konsulat Nahdlatul Ulama (NU) Sunda Kecil pada tahun 1950. Selanjutnya ketika Nahdlatul Ulama bersama-sama ormas Islam lainnya bergabung dalam Partai Majlis Syura Muslimin Indonesia (Masyumi) di Nusa Tenggara Barat, maka ia diangkat sebagai ketua Badan Penasehat Partai Masyumi untuk daerah Lombok pada tahun 1952. ${ }^{5}$

Dari 1953-1955 Tuan Guru Zainuddin menetapkan bahwa organisasi Nahdlatul Wathan menganut kebijakan "politik bebas". Artinya, organisasi ini tidak berafiliasi dengan kekuatan partai politik manapun. Sehingga merestui terbentuknya Partai Nahdlatul Ulama (NU), Persatuan Tarbiyah Islamiyah (PERTI) dan PSII di Lombok pada tahun 1953 dan 1954. Namun, pada tahun 1955, ia dan organisasi Nahdlatul Wathan memilih berafiliasi dengan partai Masyumi, sehingga ia diangkat sebagai anggota Konstituante periode 1955-1959, hasil dari pemilihan umum pertama pada tahun 1955.

Setelah partai Masyumi dibubarkan, khususnya di Pulau Lombok, Nahdlatul Wathan merupakan ormas Islam yang pertama kali dengan tegas mendukung terbentuknya Parmusi. Asumsinya, Parmusi merupakan duplikasi dari partai Masyumi. Namun dalam perkembangan selanjutnya masyarakat Nahdlatul Wathan tidak dapat berperan aktif dalam partai tersebut. Ini disebabkan tidak terakomodasinya aspirasi Nahdlatul Wathan sebagai ormas Islam yang memiliki basis konstituen terbesar di pulau Lombok. ${ }^{6}$

Selanjutnya setelah tidak aktif di Parmusi, TGKH.M.Zainuddin Abdul Madjid dan masyarakat Nahdlatul Wathan, Khususnya di Kabupaten Lombok Timur, merubah haluan politiknya dengan berafiliasi kepada Sekretariat Bersama Golongan Karya (Sekber-Golkar), suatu organisasi yang dibentuk atas gagasan Jenderal A.H Nasution. Dukungan ini didasarkan pada pertimbangan politik, bahwa Golkar adalah partai Orde Baru yang dinilai sukses menumpas G30/S PKI. Keberhasilan ini paling tidak adalah sebuah kemashlahatan bagi kaum muslimin. Dalam orgainisasi politik, aspirasi Nahdlatul Wathan lebih terakomodir dari pada partai politik lainnya. 
Pada pemilihan umum tahun 1982 afiliasi perpolitikan masyarakat Nahdlatul Wathan, khususnya Lombok Timur, oleh Tuan Guru Zainuddin mengambil politik diam atau dengan istilah Gerakan Tutup Mulut (GTM), artinya masyarakat tidak lagi disuruh untuk memilih Golkar dalam pemilu ini. Sehingga dengan sikap politik beliau saat itu, kader-kader Nahdlatul Wathan banyak yang melanggar perintah pendiri NW, sehingga saat itulah mulai terjadi konflik internal dalam tubuh NW. Kader-kader yang tetap eksis di Golkar saat itu adalah TGH. Najamuddin Ma'mun, TGH. Sakaki, TGH. Zaini Pademare, TGH. L. Zainal Abidin Sakra,dll.?

Pada pemilihan berikutnya afiliasi politik masyarakat NW, khususnya di Lombok Timur menetapkan pilihan ke Golkar setelah ada kontrak politik dengan elit-elit Golkar pada saat itu, dengan memberikan porsi yang lebih banyak di parlemen, sehingga Golkar berpikir ulang untuk tidak mengakomodir afiliasi politik masyarakat Nahdlatul Wathan, di mana politik diamnya pada pemilu 1982 menjadi kekalahan telak bagi partai Golkar.

Peta perubahan politik masyarakat Nahdlatul Wathan, secara dramatis berubah setelah meninggalnya TGKH. M. Zainuddin pada tahun 1997, kader-kader NW dan masyarakatnya ada yang tetap konsisten dengan partai Golkar ada juga yang berafiliasi kepada partai-partai baru yang dibentuk pasca Orde Baru yaitu era reformasi. ${ }^{8}$ Mengingat kondisi internal NW sepeninggal pendirinya terjadi konflik diantara kedua putri TGKH. M. Zainuddin AM; Hj.Sitti Raehanun Zainuddin Abdul Madjid (putri sulung) dan Hj. Raehanun (putri bungsu), api konflik ini berimbas kepada afiliasi politik kedua putrinya. ${ }^{9}$

Pada pemilihan umum pertama di era reformasi pada tahun 1999 kedua putri beliau ini berbeda aspirasi dalam partai politik. Hj.Sitti Raehanun Zainuddin Abdul Madjid berafiliasi pada Partai Daulat Rakyat (PDR), sementara Hj. Sitti Raehanun Zainuddin Abdul Madjid tetap pada partai Golkar. Dengan perbedaan afiliasi politik kedua putri pendiri NW ini secara tidak lansung berimbas kepada masyarakat pengikut organisasi NW.

Pada pemilu 2004 kedua kubu NW ini tetap berbeda afiliasi politiknya, untuk NW Pancor di bawah komando Hj. Sitti Rauhun Zainuddin Abdul Madjid berafiliasi ke Partai Bulan Bintang (PBB) yang kemudian menghantarkan putranya TGH. Dr. Zainul Madji, MA menjadi anggota DPR RI, sementara Hj. Sitti Raehanun Zainuddin Abdul Madjid yang berkedudukan di Anjani, mendeklarasikan Partai Bintang Reformasi (PBR) bersama KH. Zainuddin MZ di Jakarta yang kemudian menghantarkan putranya Lalu 
Gede Syamsul Mujahidin, SE menjadi anggota DPR RI dan keluarga besar NW Anjani, menjadi anggota Dewan di tingkat Provinsi, kabupaten dan kota di NTB. Secara otoritatif partai yang dideklarasikan oleh Hj. Sitti Raehanun Zainuddin Abdul Madjid lebih didominasi oleh kader-kader NW, ketimbang di Partai Bulan Bintang (PBR) yang masih didominasi kepengurusannya oleh organisasi selain organisasi NW. Melalui PBR ini kader-kader NW versi Anjani dapat duduk di parlemen baik tingkat daerah maupun tingkat nasional.

Pada pemilu tahun 2009 afiliasi politik masing-masing keluarga besar pendiri Organisasi NW ini tetap berbeda. Kubu Hj. Siti Rauhun Zainuddin Abdul Madjid berapfiliasi ke partai Demokrat besutan Susilo Bambang Yudoyono dan tampil sebagai pemenang. Sedangkan Kubu Hj. Sitti Raehanun berafiliasi pada parta politik PBR, dan dapat mengantarkan kaderkader NW sampai tingkat DPRD sedangkan untuk tingkat Pusat dengan Calon Lalu Gede Syamsul Mujahidin Memperoleh suara yang sangat signifikan tapi karena PBR tidak sampai suara nasionalnya diambang batas minimal 2\% sehingga tidak bisa menjadi anggota Dewan di tingkat Pusat.

Pada pemilihan umum legislatif tahun 2014 afiliasi keluarga besar pendiri NW ini masih tetap berbeda. Siti Rauhun dengan afiliasi ke Partai Demokrat dan pemilihan presiden ke Prabowo-Hatta. Sedangkan Sitti Raehanun berafiliasi ke Partai Hanura dan Partai PKB dan pemilihan presiden mendukung Jokowi-Jusuf Kalla. Perbedaan-perbedaan pilihan kelurga besar pendiri NW ini sedikit tidak berimplikasi kepada masyarakat akar rumput, terutama warga Nahdhatul Wathan.

Perpecahan yang terjadi di organisasi NW ini sangat berpengaruh kepada sikap politik masyarakat Islam di Lombok Timur. Sikap politik masyarakat dapat dilihat dari aspek keberpihakan mereka kepada kedua kubu NW ini. Sehingga masing-masing kubu berjuang dan bekerja ekstra keras untuk memperoleh dukungan dari masing-masing masyarakat yang notabene pengikut NW. ${ }^{10}$

Dalam konteks Lombok, hubungan mutualistik agama dan politik terlihat sejak tahun 1970-an. Para Tuan Guru telah menyalurkan aspirasi politiknya pada partai-partai tertentu, dimana mereka lagi terikat dengan cara pandang konvensional yang melihat hubungan agama dan politik secara integrated, namun sudah melihat hubungan agama-politik secara symbiosis. ${ }^{11}$

Dalam konteks inilah, menarik untuk diamati hubungan patron-klien 
yang terjadi di Nusa Tenggara Barat, di mana pemegang otoritas agama dan pemerintahan dijabat oleh seorang tokoh agama yang lazim disebut Tuan Guru. Tuan Guru dalam jabatannya merangkap sebagai amîr-umarâ' sekaligus alîm-ulamâ', memiliki posisi tersendiri di kalangan masyarakat. ${ }^{12}$

Fenomena keterlibatan para Tuan Guru dalam perubahan sosial sesungguhnya dilatarbelakangi oleh dua hal, yaitu: adanya perasaan kemasyarakatan yang mendalam dan tinggi (highly developed social sense) dan selalu mendasarkan sesuatu kepada kesepakatan bersama (General Consensus). ${ }^{13}$

Perpolitikan Tuan Guru dapat dilihat dari corak pemahaman dan karakteristik pesantren yang mereka bangun, ada yang melakoni partai politik melalui gerakan tharekat, baik tharekat naqsyabandiyah maupun tharekat qadiriyah, dll, atau melalui organisasi yang mereka pimpin, seperti organisasi NW, NU, atau Muhammadiyah, Maraqitta'limat, Dayama dan lain-lain. Secara teoritik kriteria perpolitikan politik Tuan Guru tersebut dikelompokkan dalam teori sistem politik keagamaan tradisional. ${ }^{14}$ Pergelutan politik di wilayah NTB sama sekali berbeda dengan wilayahwilayah lain yang pernah terlihat. Berbeda misalnya dengan di Jawa Barat. Di mana meskipun di Jawa Barat didominasi oleh muslim NU dan Muhammadiyah tapi yang menjadi gubernur adalah dari PKS (yang menurut anatomi keagamaan tidak berafiliasi ke NU maupun Muhammadiyah).

Di NTB, secara kesukuan terdiri dari 3 suku: suku Sasak (di pulau Lombok), suku Samawa (di Sumbawa) dan suku Mbojo (mendiami wilayah Kota Bima, Kab. Bima dan Kab. Dompu). Ketiga-tiganya memiliki anatomi politik tersendiri. Di mana di suku Sasak, sosok Tuan Guru (kyai kalau di Sundanya) sangat sentral. Ratusan Tuan Guru ada di pulau Lombok sejalan dengan ratusan pesantren yang ada di sana. Begitu juga di suku Samawa, sosok Tuan Guru pun masih menjadi sentral. Namun agak berbeda di suku Mbojo, istilah Tuan Guru tidak ada di suku ini. Sosok sentralnya malah raja, yaitu raja Bima meskipun secara teritorial tidak memiliki kawasan tetapi secara adat masih sangat eksis.

Faktor kesukuan di atas selama ini tidak terlalu bermasalah, semuanya masih bisa disatukan dalam bingkai religiusitas. Tetapi, bukan tidak mungkin, faktor kesukuan ini akan memicu konflik di kemudian hari karena perbedaan kepentingan dan wilayah. Hal krusial yang ditakutkan sebagai pemicunya adalah pemekaran "Provinsi Pulau Sumbawa" yang masih terjadi tarik-ulur. Di mana kekayaan alam terpusat di Pulau Sumbawa sementara jumlah penduduk terbanyak terpusat di Pulau Lombok, dan 
taraf hidup masyarakatnya ada kesenjangan antara Pulau Lombok dengan Pulau Sumbawa. Maka, Pulau Sumbawa berkeinginan untuk memisahkan diri dari Pulau Lombok. Ini, di kemudian hari, kalau Provinsi Pulau Sumbawa dikabulkan, bukan tidak mungkin, antara suku-suku itu akan berperang. Kecuali ada kekuatan besar lain yang dapat menyatukan hal tersebut.

70 persen penduduk NTB (yang berjumlah 5.3 juta penduduk) berada di pulau Lombok maka otomatis anatomi politik provinsi NTB berpusat di Lombok. Di mana di situ ada dua organisasi massa besar: yaitu NW (Nahdhatul Wathan) dan NU. NW sebetulnya rumpunnya sama dengan NU, di mana pendiri NW adalah juga murid dari pendiri NU. NW merupakan upaya melokalkan kearifan lokal dengan mendirikan organisasi sendiri yang sampai sekarang sangat besar. Hampir 700 pesantren berlabel NW. NU pun tak kalah besar, hanya saja jika dibandingkan dengan NW, di NTB masih besar NW. ${ }^{15}$

\section{KELUARGA BESAR NW YANG BERKOMPETISI MEREBUT KURSI PARLEMEN PADA PEMILIHAN UMUM DPR/DPRD/ DPD 2014.}

Sudah empat dekade Nusa Tenggara Barat mengalami perubahan kepemimpinan. Perubahan transisional sampai saat ini adalah bagian dari ikhtiar bangsa dengan salah satu agenda besar yang paling signifikan adalah bangkit dari keterpurukan multidimensi sehingga jelaslah setiap pemimpin selanjutnya dituntut untuk mempunyai literatur dan konsep untuk kemajuan suatu daerah. NTB adalah daerah yang terdiri dari beragam kondisi dan pola kehidupan yang membutuhkan perhatian serius oleh pemerintah. Siapapun yang akan menjadi pemimpin NTB tentunya akan menghadapi tantangan untuk menjadikan daerah ini sebagai daerah yang punya daya saing atau the competitive region. Dengan kondisi geografis yang terbentang luas lengkap dengan berbagai kekayaan alam yang terkandung di dalamnya, NTB akan bisa maju selangkah jika dipimpin oleh seseorang yang mempunyai kejelasan visi untuk memajukan NTB dan mempunyai pemimpin yang mampu membawa NTB ke arah perubahan yang jelas dan lebih baik. Paling tidak yang dibutuhkan adalah seorang yang amanah ketika menjadi pemimpin, jujur, dan adil dalam segala hal tanpa pandang bulu. ${ }^{16}$

Untuk menjawab tantangan politik yang begitu kompetitif dan dinamis, Keluarga Besar Organisasi Nahdlatul Wathan dalam dua Komando Organisasi, Pengurus Besar NW Pancor di bawah Komando TGH. Dr. M. 
Zainul Majdi, MA dan Pengurus Besar NW Anjani di bawah Komando Ummi Hj. Sitti Raehanun Zainuddin Abdul Madjid, meracik strategi yang apik untuk meletakkan calon-calon legislatif di masing-masing daerah pemilihan (Dapil) dengan harapan agar kader-kader terbaik Nahdlatul Wathan dapat terpilih menjadi anggota DPR/DPRD/DPD, guna ke depan dapat memperjuangkan aspirasi-aspirasi Warga Besar Nahdlatul Wathan di tingkat kebijakan dan kepemerintahan. Pengurus Besar NW masingmasing tentu memilih orang-orang yang loyalis terhadap khittah dan drap langkah perjuangan organisasi NW, terutama keluarga inti dari pendiri Organisasi NW yang menjadi pilihan utama dari dua putri pendiri NW ini (Ummy Hj. Sitti Rauhun ZAM dan Ummy Hj. Sitti Raehanun ZAM). ${ }^{17}$

Di antara keluarga besar Pendiri NW yang terlibat lansung dalam dunia politik praktis pada perhelatan demokrasi pemilihan umum calon legislatif 9 April 2014 adalah:

\section{TGH. L. G. M. ALI WIRASAKTI AMIR MURNI, MA.}

Menurut TGH. SAKTI, bahwa demokrasi yang sehat, menuntut kepada penghormatan terhadap tiap individu anggota masyarakat bagi kehidupan dan kebebasannya. Di samping itu menuntut pula kepada kerjasama antara individu dan ke kelompok dalam pekerjaan yang baik. Demokrasi itulah yang mendorong keberanian seseorang mencintai kebebasan yang benarbenar bersih, baik secara pribadi maupun secara kelompok yang dijiwai rasa persaudaraan dan ketulusan hati. ${ }^{18}$

Saat ini yang dihendaki adalah sesuatu kehidupan demokrasi yang di dalamnya tiap individu warga negara dan generasinya berpartisipasi, ikut berperan serta dalam menyampaikan aspirasi, hingga tidak ada seorang pun yang tertinggal di luar wilayah bangsa dan tanah airnya. Cita-cita besarnya adalah mendorong segenap warga negara agar dapat mengambil faedah dari perbedaan pendapat dan fikiran yang berkembang dari unsurunsur serta masyarakat yang ada.

Jika berpolitik mengikuti kaidah-kaidah moral, terutama etika agama, maka akibat negatif dari politik dapat dimanimalisir bahkan dapat dihilangkan. Kekuasaan tidak hanya dianggap sebagai amanat yang harus dipertanggungjawabkan di hadapan manusia, tetapi harus dipertanggungjawabkan juga di hadapan Allah SWT harus benar-benar diemban dengan sebaik-baiknya. Seorang pemimpin hendaklah bersikap adil dan bijaksana dalam menentukan suatu perkara. ${ }^{19}$ Keikutsertaan TGH. Gede Sakti di dunia 
politik praktis, sebagaimana komentarnya;

Saya terjun ke dunia politik praktis didorong oleh semangat ingin memperjuangkan ideologi perjuangan ninikda TGKH.M. Zainuddin Abdul Madjid, yang tidak cukup kita berjuang hanya dengan pendekatan kultural, yang hanya mengandalkan peran serta dan partisipasi masyarakat dalam memperjuangkan ideologi dan khittah organisasi Nahdlatul Wathan. NW sebagai organisasi terbesar di NTB membutuhkan energi dan dorongan yang kuat dari berbagai elemen masyarakat termasuk di dalamnya partai politik. bagaimana tidak kebijakan-kebijakan strategis tidak bisa ditempuh lewat pendekatan kultural tapi harus melalui pendekatan struktural dalam hal ini melalui Dewan Perwakilan Rakyat. ${ }^{20}$

Sejarah Islam membuktikan bahwa pergantian kepemimpinan dalam Islam, mulai dari kepemimpinan nabi, yang disebut dengan an-nubuwwah, merupakan tonggak awal politik di dunia Islam, bahkan boleh saya katakan di dunia agama-agama besar lainnya. Sebab politik kenabian yang dicontohkan oleh nabi menjadi tolok ukur politik dunia yang mereka sebut dengan politik yang profetik. Begitu juga pergantian kepemimpinan pasca nabi yang disebut al-Khilafah al-râsyidah merupakan awal terbentuknya sistem demokrasi di dunia, sebab demokrasi yang dipahami sekarang tidak terlepas dari sistem syura, musyawarah dalam konteks Islam. Berdasarkan hal tersebut, bagi saya politik menjadi suatu yang tidak baru bagi dunia ketuan-guruan, dan semestinya dijalankan oleh orang yang mengerti tentang etika politik profetik, ya dalam hal ini tokoh agama harus tampil di depan untuk memberikan contoh politik yang beretika profetik. ${ }^{21}$

Berangkat dari statement TGH SAKTI di atas, dapat diperjelas bahwa politik keluarga besar NW merupakan tradisi yang diwariskan oleh pendiri organisasi NW yang secara serius menekuni dunia perpolitikan. NW sebagai organisasi yang bergerak dalam tiga ranah utama, pendidikan, sosial dan dakwah, tidak akan maksimal memperjuangkan idealisasi dan konsilidasi keorganisasian jika tidak terlibat dalam dunia politik, baik masuk dalam partai politik maupun menjadi anggota parlemen.

Kontestasi politik yang dilakukan oleh TGH. SAKTI mengalami dinamika yang panjang, mulai dari Partai Bintang Reformasi besukan KH. Zainuddin $M Z$, yang lahir dari rahim era reformasi, menjadi kendaraan utama dari keluarga besar NW Anjani yang dikomandai oleh Ummi Hj Sitti Raehanun ZAM. Melalui Partai PBR keluarga-keluarga besar pendiri NW muncul ke permukaan politik menjadi anggota dewan, seperti TGH. SAKTI menjadi 
anggota DPRD Lombok Tengah 2009-2014, Syamsul Mujahidin, SE menjadi anggota DPR RI pusat 2004-2009.

Kontestasi keluarga besar NW untuk Pemilihan Umum tahun 2014, sangat dinamis, di mana masing-masing berkompetisi dalam perolehan suara di masing-masing daerah pemilihan (Dapil). TGH. SAKTI berkompetisi di daerah pemilihan Lombok Tengah dengan kendaraan politik Partai Kebangkitan Bangsa (PKB) besukan Muhaimin Iskandar. Dengan perjuangan yang kuat, dan konsulidasi politik yang konfrehensif TGH. SAKTI terpilih menjadi anggota DPRD Provinsi NTB dengan suara perolehan di Pemilu DPRD: 11.225. Peringkat 1 dari Dapil NTB 3 Partai Kebangkitan Bangsa $(\mathrm{PKB}){ }^{22}$

\section{HM. SYAMSUL LUTHFI, M.Si.}

Pada Pilkada secara lansung pada tgl 7 Juni 2008 terpilih H. Sukiman Azmy mantan Kodim Lombok Timur, dan Kabag Umum Departemen Agama, menjadi Bupati periode 2008-2014 berpasangan dengan H.M. Syamsul Lutfi sebagai wakil bupati mengalahkan dua pasangan kandidat bupati Lombok Timur: Ali bin Dahlan dan Lalu Ghafar Ismail dan Rahmat Sukardi. ${ }^{23}$

Politikus muda Nahdlatul Wathan ini, pernah menjadi Wakil Bupati Lombok Timur priode 2009-2013, melalui kendaraan politik PBB yang menghantarkannya menjadi eksekutif muda NW. Dalam dialog yang peneliti dapat rekam dari konsep politik dan keterlibatan politik H.M. Syamsul Lutfhi sebagai berikut:

Saya masuk dalam dunia politik praktis sejak saya di dunia kampus, sejak saya kuliah, tapi formalnya semenjak saya diamanahkan oleh Pengurus NW untuk masuk menjadi pengurus partai politik melalui PBB, menjadi Ketua DPD PBB Kabupaten Lombok Timur. melalui partai ini saya banyak berinteraksi dan berdialog dengan berbagai elemen komunitas dan jaringan, sehingga dengan demikian, saya dapat mengembangkan sayap organisasi NW ke berbagai elemen, terutama melalui Parlemen. Organisasi NW tidak bisa terlepas dari politik meskipun NW tidak berafiliasi atau tidak berideologi politik. Politik yang NW kembangkan adalah politik santun dan beretika, apapun khittah dan perintah politik di tubuh organisasi NW tetap mengacu pada prinsip-prinsip perjuangan NW. Inilah yang memotivasi saya untuk maju menjadi anggota Parlemen DPR RI melalui partai besukan SBY, yaitu Partai Demokrat. ${ }^{24}$ 
Kontestasi politik putra kedua dari pasangan $\mathrm{H}$. Jalaluddin, $\mathrm{SH}$, dengan Ummi Hj. Sitti Rauhun ZAM pada pemilihan umum legislatif 2014 menjadi pembuktian bahwa pengaruh besar dari kharismatik pendiri NW ini tetap menjadi daya magnet yang tidak bisa dinafikan kekuatan politik di tengahtengah kompetisi yang sengit. Artinya bahwa keluarga besar pendiri NW, NWDI, NBDI TGKH. M. Zainuddin AM, yang maju berkompetisi di ranah politik praktis, tetap menjadi pilihan masyarakat NW yang notebene masyarakat loyalis terhadap doktrin dan dogma ajaran gurunya dalam hal ini Tuan Guru. Sehingga tidak mengherankan jika keluarga besar pendiri NW jarang yang gagal dalam kontestasi politik.

Dinamika perpolitikan di tubuh organisasi NW sangat mempengaruhi konstalasi politik di NTB, di mana NW sebagai organisasi terbesar di NTB memiliki pemilih dan konstituen yang loyalis dan banyak, karena organisasi NW memang organisasi berbasis massa fanatis. dengan demikian, para politikus mesti mempertimbangkan kekuatan politik dari Kubu NW, baik NW versi Anjani maupun NW versi Pancor. Kedua-dua kubu NW ini memiliki loyalis yang kuat di akar rumput. Pertarungan politik H. Syamsul Lutfhi, untuk mencalonkan diri kembali menjadi wakil bupati priode 2013-2019 sebagai pasangan incumbent yang berpasangan dengan H. M. Sukiman Azmi, menuai kegagalan karena kurang kompaknya warga NW dalam mensukseskan Pemilukada, juga karena terbelahnya suara warga NW dengan munculnya dua keluarga inti pendiri NW yang ikut berkompetisi di Pemilukada Lombok Timur, yaitu Lale Al-yaqutun Nafis, MM, yang ikut mencalonkan diri menjadi Wakil Bupati Lotim berpasangan dengan $\mathrm{H}$. Abdul Wahab, fungsionaris Partai HANURA Lombok Timur.

Kegagalan Mereka berdua, Lutfhi dengan Yaqut pada pemilihan kepala daerah Lombok Timur tersebut, keduanya mengambil haluan politik lain dengan mencalonkan diri menjadi calon anggota legislatif DPR RI pilihan Luthfi dan Yaqut memilih tetap menjadi calon DPRD provinsi pada pemilihan Umum 2014, setelah sebelumnya terpilih menjadi anggota DPRD provinsi priode 2009-2014 dari Partai Bulan Bintang (PBB).

Syamsul Lutfhi maju menjadi calon legislatif dari Partai Demokrat untuk daerah pemilihan NTB dan terpilih sebagai anggota DPR RI dari daerah NTB dengan perolehan suara 20.000 lebih. ${ }^{25}$ Signifikansi suara yang diperoleh oleh Syamsul Lutfhi ini menunjukkan suara keluarga besar NW untuk wakil mereka di tingkat pusat sangat banyak meski harus berbagi dengan suara sepupunya yaitu Syamsul Mujahidin yang juga mencalonkan 
diri menjadi anggota DPR RI melalui kendaraan politik Partai HANURA. Pemikiran politik dan idealisasi politik H. Syamsul Lutfhi ini sedikit banyak yang dapat penulis utarakan, karena pada tahun 2013 tepatnya Oktober 2013, peneliti berangkat menunaikan ibadah Haji ke Tanah Suci Makkah bersama H. Lutfi dan tinggal satu hotel di Hotel Ajyad Makarim di Makkah kemudian di Madinah menginap di Hotel Madinah al-Mubarakah, di selasela menyelesaikan rutinitas ibadah, peneliti secara informal bertanya tentang konsep dan strategi politik yang digunakannya dalam menghadapi pemilihan umum calon legislatif pada 9 April 2014. secara umum Pak Lutfhi menjabarkan bahwa politik itu seni dan strategi. Siapapun yang ikut berpolitik harus memiliki jiwa seni dan sekaligus memiliki jiwa strategi. Strategi yang dimaksudkan Pak Lutfhi adalah strategi manejerial. Sebesar apapun modal politik yang dipunyai oleh seorang calon, tidak ada jaminan untuk dipilih oleh masyarakat, sebab masyarakat saat ini sudah lebih peka terhadap dunia perpolitikan, yang terkadang masyarakat tidak memandang Si A cucu atau anak pendiri NW yang terpenting bagi mereka siapa yang memberikan keuntungan baik keuntungan materi maupun non materi itu yang mereka pilih. Ini semua membutuhkan strategi menejerial yang efektif dan tersistematis, sehingga dengan demikian, meskipun sedikit modal, besar kemungkinan dipilih oleh masyarakat. ${ }^{26}$

\section{H. LALU GEDE SYAMSUL MUJAHIDIN, SE.}

Keterlibatan Gede Syamsul Mujahidin dalam dunia politik praktis terlihat sejak masih duduk di bangku kuliah di Jakarta. Pastinya dia masuk ke ranah politik pada era reformasi dengan masuk menjadi Pengurus Pusat Partai Bulan Bintang (PBR) sebagai Wakil Bendahara DPP PBR masa bakti 1999-2004 dan pada priode 2004-2009 terpilih menjadi anggota DPR RI utusan dari Partai Bintang Reformasi dengan suara kurang lebih 21.000 ribu suara. Pada pemilihan umum legislatif 2004-2009 maju kembali menjadi anggota legislatif DPR RI kemudian memperoleh suara terbanyak namun tidak bisa menjadi anggota DPR RI karena partai Bintang Reformasi (PBR) tidak masuk dalam ambang batas minimal 2\% suara nasional. Dengan demikian PBR harus mendaftar ulang menjadi anggota partai baru untuk bisa berkompetisi di pemilu-pemilu berikutnya.

Pada Pemilu 2014 ini, Gede Syamsul mencoba kembali menjadi calon anggota DPR RI dengan afiliasi politik dengan menggunakan kendaraan Partai HANURA dan terpilih menjadi anggota DPR RI dari Daerah pemilihan 
NTB dengan perolehan suara 19.000 suara. ${ }^{27}$

Dalam pengamatan peneliti, dan sekaligus hasil wawancara dengan bersangkutan, tentang motivasi dan argumentasi keterlibatan Gede Syamsul dalam dunia politik, sebagaimana dijabarkan dalam komentarnya:

Saya merupakan representasi warga besar NW untuk maju menjadi anggota dewan di pusat. Organisasi NW membutuhkan orang-orang yang berani menyuarakan aspirasi dan kebutuhan organisasi NW. Saya ditunjuk lansung oleh PB NW ummi Hj. Sitti Raehanun ZAM untuk maju menjadi anggota legislatif DPR RI melalui kendaraan politik HANURA.

\section{TGH. Dr. L. ABDUL MUHYI ABIDIN}

Dinasti politik di tubuh NW itu sesungguhnya semata-mata untuk melanjutkan perjuangan al-Maghfurlah Maulanasyaikh TGKH. M. Zainuddin Abdul Madjid, dan sebagai upaya kaderisasi di tubuh NW dalam aspek atau bidang Politik. NW sesungguhnya tidak bisa dilepaskan dari dunia politik meskipun NW tidak berafiliasi dalam dunia politik. Artinya secara perjuangan NW membutuhkan amunisi-amunisi kebijakan yang proaktif terhadap program-program organisasi Nahdlatul Wathan.

Menurut Menantu Ummi Hj Sitti Raehanun ZAM ini, mengomentari kifrah-kifrah perjuangan NW dalam dunia politik.

"Setiap kita sebetulnya selalu berpolitik untuk mendapatkan perhatian orang lain, seorang guru berpolitik kepada muridnya untuk mendapatkan perhatian dari mereka guna tercapai misinya sebagai seorang pendidik, begitu juga Tuan Guru, dalam menyampaikan misi dakwah dia tidak akan bisa mendapatkan perhatian masyarakat tanpa menggunakan siasat, nah siasat ini inilah yang disebut al-siyâsah dalam konteks Islam. Jadi al-siyâsah selama mengarah kepada kemashlahatan ummat dan kestabilitasan agama dan negara maka politik menurut saya sesuatu yang tidak perlu dihindari. Siyâsah dunyawiyah artinya menggunakan panggung politik hanya untuk kepentingan dunia, kepentingan pribadi dan kelompok, maka politik seperti inilah yang secara riil kita lihat dalam berbagai even pilpres, pilkada, pileg, menghalalkan segala cara, bohong sana-sini, adu domba antarsatu Tuan Guru dengan yang lain, bahwa dirinya didukung oleh si A si B, dan seterusnya. Cara politik seperti ini yang tidak dibenarkan oleh agama bahkan haram hukumnya. Sedangkan siyâsah ukhrawiyyah, politik yang mengedepankan etika moral dan mengarah kepada kepentingan umum, kepentingan masyarakat, kepentingan agama. Cara politik seperti ini menurut saya harus dilakukan oleh siapapun yang mampu untuk itu, tak terkecuali tokoh agama."28 
Dari statement di atas, penulis dapat mengembangkan visi misi politik TGH. Lalu Abdul Muhyi Abidin ini ke dalam dua dimensi: dimensi normatif, artinya politik harus dilihat sebagai sebuah aktivitas yan mengandung norma-norma agama, dan mempunyai legasi yang kuat dalam ajaran Islam, sehingga siapapun yang memiliki motivasi politik dengan mengacu pada nilai-nilai agama maka sesungguhnya dia telah masuk dalam nilainilai agama.

Petualangan politik TGH. Lalu Abdul Muhyi Abidin mulai dari anggota DPD dua periode mulai dari tahun 2009-2014. Pada Pemilihan Umum Legislatif 9 April 2014, Muhyi mengambil haluan politik menjadi anggota dewan DPRD Provinsi NTB melalui kendaraan politik PKB dengan daerah pilihan Lombok Barat dan Kabupaten Lombok Utara. Pada pertarungan politik 2014 ini, TGH Muhyi memperoleh Suara 7.781 urut kedua setelah H. Khudari Ibrahim, Lc (13.332) Dapil NTB 2 dari Partai Kebangkitan Bangsa (PKB). Dengan perolehan suara dengan nomor urut kedua di Dapil KLULombok Barat dari Partai Kebangkitan Bangsa (PKB) secara elektoral, TGH. L. Muhyi Abidin otomatis tidak terpilih menjadi anggota DPRD Provinsi NTB. ${ }^{29}$

\section{LALE YAQUTUNNAFIS, MM.}

Lale Yaqutunnafis merupakan putri ke 3 dari pasangan H. Lalu Gede Wiresentane, dengan Ummi Hj. Siti Raehanun Zainuddin Abdul Majid. Secara geneologi Yaqut merupakan cucu pendiri NW, NWDI, NBDI yang sedikit tidak sangat berpengaruh dalam percaturan politik di NTB. Terbukti bahwa Yaqut terpilih menjadi anggota DPRD Provinsi NTB pada masa bakti 2009-2014 dari kendaraan politik PBB. Pertaruhan politik Yaqut dari tahunke tahun menambah kecenderungan politiknya yang membuat dirinya semakin matang dengan dunia politik.

Menurut Yaqutunnafis, "Politik, tidak serta merta dilihat dari aspek negatifnya saja, tapi politik itu juga harus dilihat dari fungsi dan manfaatnya. Politik dengan kaca mata negatif melihatnya jelas yang kelihatan adalah politik kotor, politik saling menjatuhkan, dan sebagainya, tapi jika dilihat dari kacamata agama politik juga pernah dilakukan oleh Nabi Muhammad SAW dalam menjalankan roda pemerintahan di Madinah, yang melahirkan Piagam Madinah, sebagai landasan operasional politik yang dicetuskan oleh nabi dalam memahami pluralitas masyarakat 
Madinah. Nah, kita tidak antipati terhadap politik, tapi mari mencontoh cara politik Nabi yang lebih etik dan mengedepankan kemashlahatan ummat." 30

\section{H.M KHAIRUL RIZAL, ST., MT.}

Terpilihnya H.M. Khairul Rizal sekaligus menantu dari Ummi Hj Sitti Rauhun ZAM, suami dari Dr. Hj.Sitti Rohmi Djalilah, M.Pd. Putri Sulung Ummi HJ. Sitti Rauhun ZAM dengan H. Jalaluddin dengan memperoleh suara 6.725 daerah pemilihan Lotim 1 mengantarkannya menjadi anggota DPRD Kabupaten Lombok Timur dengan menggunakan kendaraan Partai Demokrat sebagai partai pengusungnya sekaligus dinobatkan sebagai Ketua DPRD Kabupaten Lombok Timur dikarenakan Partai Demokrat sebagai pemenang.

Kesuksesan H. M. Khairul Rizal ini tentu tidak terlepas dari nama besar keluarga TGKH. M. Zainuddin Abdul Madjid yang sudah mengakar di masyarakat Lombok Timur, juga ditentukan oleh efektivitasnya Partai Demokrat yang di bawah komando Adik Iparnya sendiri, Syamsul Luthfi untuk DPD Lombok Timur dan TGH. Zainul Majdi untuk DPD Provinsi NTB dalam mensosialisasikan dan mengkampanyekan calon dari Keluarga besar dari putri sulung TGKH. M. Zainuddin Abdul Madjid.

\section{H.RUKLI DJUHAIDI}

Menantu dari Ummi Hj Sitti Raehanun ZAM, Suami dari Hj. Lale alYaquutunnafis. Suara 6.334 Urut 1 dapil NTB 3 Dari Partai Kebangkitan Bangsa (PKB). Politisi senior ini gagal melaju ke parlemen karena persaingan antar calon yang tidak diantisipasi dengan baik dan cermat, terutama calon dari organisasi Nahdlatul Wathan yang berafiliasi ke organisasi Nahdlatul Wathan versi Anjani.

\section{Hj. RABIATUL ADAWIYAH, SE.}

Hj. Rabiatul Adawiyah paling tidak pernah menjadi anggota utama Keluarga Besar Pendiri Nahdlatul Wathan melalui jalur Ummi Hj. Sitti Rauhun Zainuddin Abdul Madjid dengan dipersunting menjadi Istri oleh Putra beliau, TGH. Dr. Muhammad Zainul Majdi, MA, yang saat itu sedang menjabat sebagai gubernur periode pertama (2008-2013) namun diceraikan pada tahun 2013 karena tidak siap dipoligami. Pada pemilihan 
Umum tahun 2014 Rabiatul Adawiyah mencalonkan dirinya menjadi anggota DPD RI utusan NTB dan terpilih dengan perolehan suara signifikan sehingga dapat mengantarkan dirinya ke Senayan sebagai Dewan Perwakilan Daerah. Ini menurut para pengamat politik, sebab utama keberhasilan Rabiah Adawiyah polularitas yang dimilikinya semenjak mendampingi TGH. M. Zainul Madji sebagai istri Gubernur. ${ }^{31}$ Juga karena faktor jumlah pemilih perempuan di NTB lebih banyak dari jumlah pemilih lakilaki. Hal ini berdampak kepada afiliasi pilihan perempuan kepada Rabiah Adawiyah. Alasan perempuan memilih sesama perempuan sesuai hasil wawancara peneliti, adalah sebagai rasa solidaritas sesama perempuan yang saat itu Ibu Rabiah sudah diceraikan oleh suaminya dan tentu tampilnya Rabiah Adawiyah di pentas politik praktis memberi warna terhadap dinamika politik di kalangan internal keluarga pendiri NW. ${ }^{32}$

\section{FAKTOR KEBERHASILAN KELURGA BESAR NW DALAM MERAIH TIKET KE PARLEMEN TAHUN 2014.}

\section{Posisi Strategis Tuan Guru NW di Tengah Masyarakat}

Di antara faktor utama keberhasilan politik praktis Keluarga Besar ELIT NW di NTB tidak terlepas dari posisi para Tuan Guru di kalangan masyarakat Islam Sasak, sebagai fungsionaris agama adalah orang atau orang-orang yang menjalankan fungsi-fungsi kepemimpinan agama; memimpin dan mengarahkan para pemeluk agama; seringkali bukan hanya dalam urusanurusan agama (sakral) seperti keimanan (teologi), ibadah, ritual, dan sebagainya, tetapi juga dalam urusan-urusan yang lebih bersifat keduniaaan (profan). ${ }^{33}$

Di masyarakat Lombok, tatanan-tatanan masyarakat amat sangat tergantung kepada apa dan bagaimana ajaran Tuan Guru yang dijadikan sebagai panutan. Manakala Tuan Guru mereka lebih mengedepankan doktrin dan prinsip-prinsip yang diterima oleh akal dan naluri mereka, atau apabila doktrinnya lebih mengedepankan ajaran-ajaran tasawuf, maka secara otomatis dalam aplikasi kehidupannya lebih tercermin corak-corak sufisme, yang tentunya sesuai dengan ajaran tasawuf (tarekat) yang diterima dari Tuan Gurunya. ${ }^{34}$

Kedudukan Tuan Guru sebagai sosok ulama dalam masyarakat, telah mendapatkan kepercayaan dan telah diakui sebagai pemimpin, umumnya bersifat non-formal, kewibawaan mereka kerapkali melebihi pemimpinpemimpin formal, mereka umumnya disegani, dipatuhi, dan juga dicintai. 
Ada beberapa aspek yang membentuk kepemimpinan Tuan Guru sebagai tokoh agama dalam kehidupan masyarakatnya. ${ }^{35}$

Pertama, aspek intelektual, yang melatarbelakangi kepribadian ulama. Aspek ini meliputi kriteria keulamaan, yang berupa penguasaan ilmu-ilmu agama Islam, pengakuan masyarakat, karakteristik pribadi tercermin dalam moralitas yang dianutnya dan hubungan genealogis dimana tradisi pesantren dalam hal ini masih kuat. $^{36}$

Kedua, aspek fungsional, yang berkaitan dengan peran nyata Tuan Guru/ulama secara konkrit dalam kehidupan masyarakatnya. Fungsi kepemimpinan Tuan Guru secara umum memiliki tiga sifat utama, pertama, memimpin penyelenggaraan upacara peribadatan (ritus) keagamaan. Kedua, menjadi tempat bertanya bagi masyarakat dalam banyak hal (seperti kehidupan keluarga, keamanan dan pengobatan). Ketiga, menjadi teladan dalam tingkah laku sosial (qudwah hasanah). ${ }^{37}$

Ketiga, aspek status sosial, baik yang bersifat universal maupun status faktual yang dihayati masing-masing. Aspek status sosial membagi para ulama/Tuan Guru ke dalam dua kategori besar, yaitu: a) ulama yang mempunyai status sosial vertikal, sebagai tokoh organisasi dengan suatu hirarki yang jelas, baik dalam ukuran nasional maupun international. b) ulama/Tuan Guru yang mempunyai status sosial horizontal, yang umumnya berpusat di pesantren-pesantren. Mereka tidak menduduki jabatan-jabatan formal dalam organisasi kemasyarakatan, tetapi mempunyai pengaruh yang mendalam pada masyarakat. ${ }^{38}$

Keempat, aspek kekerabatan, yakni membentuk jaringan kepemimpinan antar keluarga ulama/Tuan Guru. Cara praktis yang mereka tempuh untuk membangun solidaritas dan kerjasama tersebut adalah: mengembangkan suatu tradisi bahwa kelurga yang terdekat harus menjadi calon kuat pengganti kepemimpinannya, kepemimpinan ini berlaku dalam kepemimpinan pesantren. Mengembangkan suatu jaringan aliansi perkawinan endegonis (satu lingkungan) antar keluarga ulama/Tuan Guru. Mengembangkan tradisi transmisi keilmuan pengetahuan dan rantai transmisi intelektual antara Tuan Guru dan keluarganya. Dengan cara ini para Tuan Guru saling terjalin dalam ikatan kekerabatan yang intensitas tali-temalinya sangat kuat. Semakin masyhur kedudukan seorang Tuan Guru, semakin luas jaringan kekerabatannya dengan ulama lain. ${ }^{39}$ 
Organisasi Nahdlatul Wathan sebagai sebuah organisasi yang bergerak dalam bidang pendidikan, sosial dan dakwah islamiyah, telah berkiprah nyata dalam perubahan sosial masyarakat NTB. Karena kiprahnya yang nyata tentu dapat memberikan ruang bagi pengurus organisasi untuk menjadikannya sebagai media dan sarana politik dengan segala argumentasi dan alasan yang membenarkan organisasi NW mengambil ranah politik dalam berjuang.

\section{FAKTOR KEGAGALAN SEBAGIAN AKTOR KELUARGA BESAR NW DI RANAH POLITIK.}

Dalam berbagai sumber yang diwawancara dan berdasarkan pengamatan dan keterlibatan lansung penulis terkait Pilkada tahun 2014 dalam hal survei dan studi kelayakan para calon dari Organisasi Nahdlatul Wathan, penulis dapat merangkum secara garis besar faktor kegagalan utama keluarga besar NW dalam kontestasi politik praktis pemilu tahun 2014 dibagi menjadi dua faktor utama:

\section{Faktor Internal Organisasi}

Pertama, konflik internal Organisasi NW. Perpecahan kedua kubu kepengurusan NW yang sama-sama mengklaim diri sebagai pengurus NW yang sah menjadikan masyarakat NW pada tingkat bawah terpecah belah akibat saling mencari pengaruh dan pengikut pada masing-masing kubu. Tidak sedikit konflik internal yang terjadi akibat dualisme kepengurusan organisasi NW ini, antara lain, konflik berdarah antara Hizbullah (satgas di bawah komando Hj. Sitti Raehanun ZAM) dengan Satgas Hamzanwadi (di bawah komando Hj. Sitti Rauhun ZAM) di Kesik Masbagik, Lombok Timur, pada tahun 2000. Begitu juga konflik berdarah terjadi di Wanasaba tahun 2002, dan pada tahun 2003 terjadi pengusiran pengikut $\mathrm{Hj}$. Raehanun di Paok Lombok Suralaga Lombok Timur. ${ }^{40}$ Kedua, Persaingan antar keluarga di daerah pemilihan yang sama. Kegagalan yang tidak kalah pentingnya juga disebabkan karena ketidak lihaian dalam menentukan zona daerah pemilihan (DAPIL).

\section{Faktor eksternal}

Pertama, kurangnya sami'na wa atho'na (loyalitas) terhadap instruksi dan arahan pimpinan organisasi NW. Doktrin sami'na wa atha'na dalam 
organisasi NW telah terjadi pergeseran peran dan fungsi, di mana era saat ini konsep sami'na wa atho'na terhadap pimpinan organisasi NW sudah mulai mengikis dan berkurang, berbeda halnya di era pendiri NW masih hayat, doktrin sami'na wa atho'na merupakan doktrin yang sangat sakral dan terpatuhi. Ketidak sami'na wa atho'na (tidak mendengar dan tidak taat) terhadap instruksi Pengurus Besar NW semisal instruksi PB NW hasil Muktamar Praya Ummi Hj. Sitti Raehanun Zainuddin Abdul Madjid berdampak terhadap tidak terpilihnya paket WALI (Wahab-Lale Yaqutunnafis) yang diusung oleh NW yang berdomisili di Anjani, atau tidak terpilihnya kader-kader NW di tingkat legislatif dari kubu Anjani juga karena tidak taatnya terhadap instruksi PB NW. Begitu juga gagalnya paket Sukiman-Lutfi yang diusung oleh PB NW hasil Muktamar Reformasi yang berpusat di Pancor, Dr. TGH. Zainul Majdi, MA juga tidak terlepas dari kurangnya ketaatan warga NW terhadap instruksi para pimpinan NW.

Model relasi sami'na wa ato'na sebenarnya menjadi kunci untuk meningkatkan partisipasi jamaah dalam pemilihan umum. Salah satu cara untuk meningkatkan partisipasi tersebut melalui "pengajian edukasi politik" yang mana sering kali konten dalam pengajian yang diselipkan dengan pentingnya berpartisipasi dalam pemilihan umum. ${ }^{41}$ Dengan kurang memperhatikan jargon tersebut banyak kebijakan politik NW yang tidak berhasil.

Kedua, Strategi kampanye dan manajemen politik yang tidak optimal. Menurunnya trust masyarakat terhadap calon Incumbent. Ketiga, kurang menjaring aspirasi ke tingkat bawah akar rumput. Keempat, tidak cukup mengandalkan nama besar NW tapi membutuhkan modal politik (cost politic) yang tidak sedikit. Kelima, berbeda-bedanya kendaraan politik yang digunakan. Keenam, terlambatnya menentukan pasangan calon dalam pilkada.

Implikasi Jaringan Keluarga dan Organisasi NW terhadap Kekuasaan Gubernur NTB

Implikasi Positif:

a. Memperkuat legitimasi kekuasaan gubernur di parlemen.

b. Memperluas jaringan keorganisasian ke pentas politik nasional bahkan internasional.

c. Memperluas jaringan penyebaran organisasi Nahdlatul Wathan ke level yang lebih tinggi.

d. Memperkuat basis ekonomi organisasi NW ke arah yang lebih mapan. 
Implikasi Negatif:

a. Terjadinya persaingan politik antar keluarga besar NW.

b. Terjadinya blok-blok keluarga yang terlihat tidak harmonis secara politis bahkan secara organisatoris.

\section{KESIMPULAN}

Kontestasi keluarga besar Nahdlatul Wathan yang berkaitan dengan suksesi kepemimpinan, politisasi birokrat maupun sosialisasi tokoh informal masyarakat menjadi bagian intimitas yang bertindak sebagai agen intermediasi dalam memenangkan dan melanggengkan kekuasaan famili politik. Perbincangan mengenai dinasti politik dalam ranah politik lokal sangatlah berbeda dengan konteks dinasti politik yang terjadi di level nasional. Dalam ranah lokal, romantisasi nama besar familisime menjamin suatu dinasti politik dapat eksis secara terus-menerus.

Nahdlatul Wathan sebagai organisasi keagamaan yang didirikan pada tahun 1953 oleh TGKH. M. Zainuddin Abdul Madjid merupakan organisasi yang dapat mewarnai dinamika politik di Provinsi NTB, meskipun organisasi Nahdlatul Wathan menegaskan dirinya hanya bergerak pada tiga domain utama; pendidikan, sosial dan dakwah Islamiyah. Meskipun demikian, Nahdlatul Wathan selalu mengambil posisi yang strategis dalam kancah perpolitikan di NTB. Hal ini terlihat dalam beberapa aspek: Pertama, aspek partai politik yang didukungnya. Kedua, aspek modal sosial yang dimilikinya dan ketiga aspek peranan organisasi yang masif. Ketiga aspek tersebutlah, Nahdlatul Wathan dan Keluarga Besar Nahdlatul Wathan selalu ikut berpartisipasi dalam merebut kekuasaan melalui lembaga eksekutif maupun legislatif. Kajian ini menegaskan bahwa pilihan organisasi Nahdlatul Wathan untuk tidak berpolitik praktis susah dibedakan dengan pilihan Keluarga Besar Nahdlatul Wathan yang terjun ke dunia politik praktis. Sedikit tidak akan bias antara khittah organisasi dengan kepentingan Keluarga Besar Nahdlatul Wathan yang bisa memanfaatkan organisasi Nahdlatul Wathan menjadi tunggangan politik meraih kekuasaan terlepas dari apapun motivasinya.

\section{CATATAN AKHIR}

1 Daniel Fitzpatrick, "Indonesian Corporate Governance", dalam Chris Manning (ed.), Indonesia in Transition, (Singapura: ISEAS, 2000), h. 293-306.

2 Nathan Allen, Clientelism and the Personal Vote in Indonesia, (Ottawa: CPSA, 
2012), h. 7.

3 Daniel Fitzpatrick, Indonesia in, h. 293-306

4 Fahrurrozi, Tuan Guru: Eksistensi dan Tantangan Peran dalam Transformasi Masyarakat, Cet. 1, (Jakarta: Sanabil Press, 2016), h. 211.

5 Muhammad Nur, dkk., Visi Kebangsaan Religius: Refleksi Pemikiran dan Perjuangan Tuan Guru Kyai Haji Muhammad Zainuddin Abdul Madjid 1904-1997, Cet. 1, (Jakarta: Logos Wacana Ilmu. 2004), h.245

6 Muhammad Nur, dkk., Visi Kebangsaan, h.246.

7 Konflik internal yang terjadi antara pendiri NW dan murid-muridnya ini disebabkan karena kelihaiannya Partai Golkar mengadakan pendekatanpendekatan personal kepada tokoh-tokoh Tuan Guru-Tuan Guru yang dianggap berpengaruh di wilayahnya masing-masing. Pendekatan-pendekatan personal kepada Tuan Guru yang notabene pengikut setia TGKH. M. Zainuddin yang dilakukan oleh Golkar dan penguasa pemerintah saat itu, membuat para Tuan Guru tersebut tidak mengindahkan seruan dan perintah TGKH. Zainuddin untuk "diam” tidak menjadi juru kampanye Partai Golkar. Ketidakpatuhan mereka itu terhadap anjuran dan seruan TGKH. M. Zainuddin membuat hubungan antara guru dan murid merenggang bahkan terputus. TGH. M. Najamuddin keluar dari organisasi NW dengan membuat lembaga pendidikan sendiri, Darul Muhajirin Praya, begitu juga TGH. Zainal Abidin Sakra membuat lembaga pendidikan, Darul Abidin Sakra, TGH. Sakaki membentuk lembaga pesantren, dan lain-lain. (Lihat, Fahrurrozi, Tuan Guru..h. 24).

8 Era reformasi terjadi pada tahun 1998 dengan adanya tuntutan mahasiswa untuk mendesak Presiden Suharto untuk meletakkan jabatannya menjadi presiden karena tuduhan KKN (Korupsi, Kolusi dan Nepotisme). Mahasiswa menduduki gedung MPR/DPR berhari-hari sehingga pada tgl 20 Mei 1998 Presiden Suharto pada saat itu menyerahkan estafet kepemerintahan kepala negara kepada Wakil Presiden B.J. Habibie. Di era B.J. Habibie inilah keran politik dan kebebasan berpendapat dibuka lebar-lebar. Pada era B.J.Habibie berjamuran partai-partai politik yang ikut menjadi kontestan pada pemilu 1999, pemilu pertama di era reformasi.

9 Hajjah Siti Rauhun dan Hajjah Siti Raehanun diistilahkan oleh pendiri NW sebagai Rauhun wa Raihanun, artinya dua putri beliau ini diharapkan tetap eksis membela organisasi Nahdlatul Wathan sesuai kapasitasnya masingmasing. Kedua putri pendiri NW ini dipersunting tokoh-tokoh berpengaruh untuk konteks Lombok saat itu, Hajjah Rauhun dipersunting pertama kali oleh H. Jalaluddin, SH, dari Apitaik. Seorang intelektual dan ahli birokrasi, sehingga dengan keahliannya tersebut, menghantarkannya menjadi Pengurus Besar Nahdlatul Wathan pada tahun 1962-sampai 1972. kemudian menikah lagi dengan Drs. H.M Syubli. Sedangkan Hajjah Sitti Raehanun dipersunting oleh seorang keturunan Raja Bonjeruk Drs. H. Lalu Gede Wiresentane, seorang birokrat, yang kemudian menjadi Pengurus Besar NW pada periode 1984-1997. Dari keturunan kedua putri dan menantu pendiri NW inilah 
diharapkan menjadi penerus perjuangan NW ke depan.

10 Saipul Hamdi, "Politik Islah: Re-Negosiasi Islah, Konflik, Dan Kekuasaan Dalam Nahdlatul Wathan di Lombok Timur”, Jurnal Kawistara, No. 1. April 2011, h. 1-102.

11 Muhammad Abdun Nasir, dkk, "Polarisasi Thariqat QadhariyahNaqsyabandiyah Lombok Pada Pemilu 2004”, Jurnal Istiqro', Vol. 05, No.01, 2006, h. 104.

12 Muhammad Syukri, Wawancara Pribadi, Tgl 12 September 2015 di Mataram.

13 Suprapto, "Pesantren dan Pemberdayaan Masyarakat: Menimbang Aktivitas Dakwah bi al-Hal Pesantren di Lombok", Jurnal Tasamuh, Vol. 4, Nomor 1, Desember 2006, h. 94.

14 Saipul Hamdi, "Politik, Agama dan Kontestasi Kekuasaan Nahdlatul Wathan di Era Otonomi Daerah Lombok NTB”, Jurnal Review Politik, Vol. 1, No. 2 Agustus 2011, h. 2.

15 http://politik.kompasiana.com/2013/04/09/anatomi-politik-di-ntb-padapilgub-2013-549646.html

16 Zulkarnain, Tuan Guru Bajang Berpolitik dengan Dakwah dan Berdakwah dengan Politik: Menata Pluralitas di Balik Tabir politik, (Pare Kediri: Kaysa Madia, 2008), h. 56.

17 Coba cermati pemikiran politik TGKH. M. Zainuddin Abdul Madjid dalam karya monumentalnya, Wasiat Renungan Massa: Pengalaman Baru, Karya ini ditulis dalam rentang waktu 5 dekade, dan ditulis dalam bentuk syair dengan sajak AB AB. Ajibnya terkadang di partai Islam, berpura-pura membela Islam, aktif keliling siang dan malam, membela diri melupakan Islam (Wasiat. 142, h. 55). Karena kafir tak pandai bersyukur, penuh khulaya' hasad takabbur, tidak hiraukan teman dan batur, semau-maunya berpolitik catur (Wasiat. No. 152). Janganlah nanda dibikin bubur, oleh pemain politik catur, diperalat untuk melawan batur, sehingga ukhwah hancur dan lebur (Wasiat. No. 152, h.165). Banyak sekali berlidah madu, berhati pahit bagai empedu, berpolitik "Membelah Bambu", tujuannya ummat jangan bersatu (Wasiat. No. 166, h.165). Politik satu ditambah satu, ditambah satu sama dengan satu, dilancarkan oleh golongan tertentu, membela nafsu membela hantu (Wasiat. 168, h. 62). Kalau iman seorang tidak di dalam, politik juangnya hanya menghantam asalkan dunia dan fulus digenggam, tidak perduli taqwanya tenggelam (Wasiat. 190, h. 62). Lisan politik dan tukang dongeng, pandai memikat jutaan kepeng, menawan menteri berumah genteng, 'Semet Bulu Mau' Banteng” (Wasiat. 190, h. 141). Dalam politik bermain curang, ke kiri kanan aktif menendang, sehingga tak regan membayar hutang, dengan NW nya pada seorang (Wasiat no. 53, h. 46.) Dalam politik bermain curang, ke kiri kanan aktif menendang, sehingga tak segan membayar hutang, Dengan NW nya pada seorang (Wasiat No. 53, h. 46). Si keranjingan gila politik, lupa dirinya kejungking-balik, iman taqwanya hilang geritik, na'uzubillah mimma hunalik (Wasiat No. 113, h. 46). Agama bukan sekedar ibadah, puasa sembahyang di atas sajadah, tapi agama mencakup aqidah, Mencakup syari'ah 
mencakup hukumah (mansukh) (Wasiat No. 78, h. 46.

TGH. L. Gede Sakti, Wawancara Pribadi, Mataram, 23 Maret 2014.

19 TGKH Muhammad Zainul Majdi, Islam, h.229, dia mengutip firman Allah surat An-Nisa' ayat: tentang etika kepemimpinan, yang artinya, "hai orangorang yang beriman jadilah engkau orang yang benar-benar penegak keadilan, menjadi saksi karena Allah biar terhadap dirimu sendiri, atau ibu-bapak dan kaum kerabatmu, jika ia kaya ataupun miskin, maka Allah lebih tahu kemashlahatannya. Maka janganlah kamu mengikuti hawa nafsumu karena ingin menyimpang dari kebenaran, jika kamu memutarbalikkan kata-kata atau enggan menjadi saksi, maka sesungguhnya Allah adalah Maha Mengetahui segala apa yang kamu kerjakan."

20 TGH. L. Gede M. Ali Wirasakti Amir Murni, Wawancara Pribadi, 25 Maret 2014 di Mataram

21 TGH. L. Gede M. Ali Wirasakti Amir Murni, Wawancara Pribadi, Tgl 27 Maret 2014 di Ponpes Syeikh Zainuddin NW Anjani.

22 Data disadur di dokumen KPU Provinsi NTB.

23 Sumber data dari KPUD Lombok Timur.

24 H.M. Syamsul Luthfi, M.Si, Wawancara Pribadi, 26 Maret 2014 di Pancor, Lombok Timur.

25 Data jumlah suara untuk Syamsul Lutfi ini diolah dari data KPUD Prov NTB tahun 2014.

26 Peneliti olah bahasa dan argumentasinya sesuai hasil wawancara peneliti dengan informan

27 Data perolehan suara calon anggota DPR/DPRD disadur dari dokumen KPUD NTB 2014.

28 TGH.L. Muhyi Abidin, Wawancara Pribadi, TGl, 1 April 2014 di Ponpes Syaikh Zainuddin NW Anjani, Lombok Timur.

29 Dokumen KPU Provinsi NTB, Tahun 2014, dikutip pada tanggal 22 Maret 2015

30 Wawancara Pribadi, tgl 30 Maret 2014 di Mataram.

31 Kadri, Analis Politik NTB, Wawancara, di Mataram, 22 Agustus 2014

32 Tim Relawan Penggerak Perempuan, Wawancara, di Mataram, 25 Agustus 2014

33 Emital Etzion \& Eva Etzioni Halevy, Social Change: Sources, Patterns and Consequences, Second Edition, (New York: Basic Book, Inc., Publisher, 1973), h. 374. Tentang Group Dynamics and Social Change based on Leader Personality.

34 Fahrurrozi Dahlan, Sejarah Perjuangan dan Pergerakan Dakwah Islamiyah Tuan Guru Haji Muhammad Mutawalli di Pulau Lombok, (Jakarta: Sentra Media, 2006), h. 12. lihat juga refrensinya dalam,., Safia Iqbal, Leadership of Women: In The Light of Quran, Sunnah, and Ominent Muslim Jurists, (Lahore: Publecation Press 1td, 1990)., Jim Shaffer, The Leadership Solution, (New York: McGrow Hill-Book, 2000), (the communication fuction part six), George Manning, The Art of Leadership, (New York: Mc Grow Hill, 2003).

35 Pengakuan masyarakat tentang eksistensi Tuan Guru sebagai pemimpin keagamaan sangat kelihatan perannya, di mana Tuan Guru masih dianggap 
sosok penyelamat yang akan membawa mereka ke arah kebenaran. Pengakuan tulus masyarakat tersebut secara rasional memang perlu dipertanyakan, tapi dalam konteks sosiologis itu sudah menjadi tradisi yang turun-temurun dalam upaya mereka menghormati orang yang dituakan, baik kapasitasnya sebagai Tuan Guru warisan dalam arti bapaknya Tuan Guru, maka anaknya secara otomatis menduduki warisan ke-Tuan Guru-annya meskipun keilmuannya lemah, maupun Tuan Guru yang dibentuk karena keilmuan yang memadai.

36 Untuk melihat keperibadian seseorang secara individu dari luar, dapat dilihat dan diukur dengan menilai ekspresi-ekspresi dari karakteristik keperibadian. Adapun karakteristik-karakteristik dimaksud adalah, penampilan fisik, tempramen, kecerdasan dan kemampuan, arah minat dan pandangan mengenai nilai-nilai, sikap sosial, kecenderungan-kecenderungan dalam motivasinya, cara-cara pembawaan diri, dan kecenderungan patologis, h. 82, lihat juga M. Noor, dkk., Visi Kebangsaan, h. 159.

37 Muhammad Tholhah Hasan, Islam, h. 64.

38 Imam Bawani, Tradisionalisme dalam Pendidikan Islam, (Surabaya: al-Ikhlas, 1993), h. 90.

39 Pola kepemimpinan Tuan Guru dapat pula dianalisis melalui enam ciri-ciri utama kepemimpinan sebagaimana yang dikatakan oleh Hickman dan Tinus, yang kemudian dikutip oleh Riswandi Imawan, Pertama, Intelectual capacity, yang berhubungan dengan kepandaian dan ketajaman otak seseorang untuk mengatur dan merencanakan gerak organisasi yang dipimpinnya. Kedua, self significance, yakni perasaan dirinya penting untuk membantu mencapai tujuan kelompok. Ketiga, cavability, yang menunjuk kepada semangat kerja dan kesehatan seseorang. Keempat, training, tambahan yang diterima seseorang agar memiliki kemampuan yang lebih baik daripada orang lain. Kelima, experince, yaitu pengalaman memimpin yang dimiliki seseorang sekalipun pada kelompok kecil. Keenam, refutation, yaitu refutasi yang dimiliki seseorang dalam menyelesaikan tugasnya dengan tanpa cacat atau tercela. (Riswandi Irawan, Membedah Politik, h. 23)

40 Saipul Hamdi, Nahdlatul Wathan di Era Reformasi: Agama, Konflik Komunal dan Peta Rekonsiliasi, Cet. 1 (Yogyakarta: KKS Yogyakarta, 2014), h. 200-201.

41 Rifki Maulana Iqbal Taufik, Nahdlatul Wathan dan Misi Kebangsaan: Menilik Peran Nahdlatul Wathan Dalam Memajukan Demokrasi Di Lombok - Nusa Tenggara Barat, h. 9. artikel lepas, diakses pada tanggal 22 Agustus 2016.

\section{DAFTAR PUSTAKA}

Heywood, Andrew. 2002. Politic. British: Palgrave. Second Edition.

Cohen, Aaron. 1999. "Politik And Workplace, An Empirical Examination or

The Relationship Between Political Behavior And Work Outcomes." Public Productivuty \& Managmen Review, Vol. 22, No. 3.

Nathan, Allen. 2012. Clientelism and the Personal Vote in Indonesia. Ottawa: CPSA. Asako, Y. 2010. Dynastic Legislators: Theory and Evidence from Japan. Madison:

University of Wisconsin Press. 
Arikunto, Suharsini. 1998. Prosedur Penelitian. Jakarta: Rieneka Cipta.

Bathoro, Alim. 2011. "Perangkap Dinasti Politik dalam Konsolidasi Demokrasi." Jurnal FISIP Umrah, Vol. 2, No. 2. h. 115-125.

Badoh, Ibrahim. 2010. "Nepotisme ala Reformasi: Pelanggengan Kuasa Orba lewat Sekongkol Bisnis Politik.” Asasi. h. 1-24.

Budiarjo, Miriam. 1982. Dasar-dasar Ilmu Politik. Jakarta: Gramedia.

Cesar, Julius. 2013. Political Dynasties in Indonesia and The Philippines. RSIS commentary. $1-4$

Dahlan, Fahrurrozi. 2006. Sejarah Perjuangan dan Pergerakan Dakwah Islamiyah Tuan Guru Haji Muhammad Mutawalli di Pulau Lombok. Jakarta: Sentra Media.

Dinasti H. TB. Chasan Sochib: Sang Gubernur Jenderal dari Banten.” 2011. Konstelasi, April. Diakses 8 Desember 2012 (http:// www.p2d.org/index.php/ kon/52-31-april-2011/273-dinasti-h-tbchasan- sochib-sang-gubernur-jenderaldari-banten.html).

Djati, Wasisto Raharjo. 2013. Revivalisme Kekuatan Familisme. Jurnal Sosiologi MASYARAKAT, Vol. 18, No. 2.

Djati, Wasisto Raharjo. "Refifalisme Kekuatan Familisme dalam Demokrasi: Dinasti Politik Aras Lokal.” Jurnal Sosiologi MASYARAKAT.

Duverger, Maurice. 2005. Sosiologi Politik. alih bahasa oleh Daniel Dakidai. Jakarta: Raja Grafindo Persada.

Etzion, Emital dan Eva Etzioni Halevy. 1973. Social Change: Sources, Patterns and Consequences, Second Edition. New York: Basic Book, Inc., Publisher.

Fasya, Teuku Kemal. 2012. Istri-istri jadi Bupati. Jurnal Nasional, Desember.

Fitzpatrick, Daniel. 2000. Indonesian Corporate Governance. dalam Chris Manning (ed.). Indonesia in Transition. Singapura: ISEAS.

Gaffar, Affan. 2001. Politik Indonesia: Transisi Menuju Demokrasi. Yogyakarta: Pustaka Pelajar.

Garzon, Adela. 2002. Familism. dalam En J. Ponzetti (Ed.). International Encyclopedia of Marriage and Family. New York: MacMillan.

Haboddin, Muhtar. 2012. Kemenangan Karaeng dalam Pilkada. Jurnal Aliansi.

Hadi, Sutrisno. 1973. Metodologi Research Jilid II. Yogyakarta: Yayasan Penerbitan Psikologi UGM.

Hamdi, Saipul Nahdlatul Wathan di Era Reformasi: Agama, Konflik Komunal dan Peta Rekonsiliasi, Cet. 1. Yogyakarta: KKS Yogyakarta.

Hamdi, Saipul. 2011. "Politik, Agama dan Kontestasi Kekuasaan Nahdlatul Wathan di Era Otonomi Daerah Lombok NTB”, Jurnal Review Politik, Vol. 1, No. 2 Agustus.

Hamdi, Saipul. 2011. "Politik Islah: Re-Negosiasi Islah, Konflik, Dan Kekuasaan Dalam Nahdlatul Wathan di Lombok Timur”. Jurnal Kawistara, No. 1. h. 1102.

Hamid, Abdul. 2010. Memetakan Aktor Politik Lokal Banten Pasca Orde Baru. Jurnal Politika.

Haris, Syamsudin. 2007. Pemilu Langsung di Tengah Oligarki Partai. Jakarta: 
Gramedia Pustaka Utama.

Harjanto, Nico. 2011. Politik Kekerabatan dan Institusionalisasi Partai Politik di Indonesia. Analisis CSIS.

Haryanto. 2007. Kekuasaan Elite: Suatu Pengantar. Yogyakarta: PolGov Press.

Hernowo, M. 2012. Daerah yang Dibelit Politik Uang dan Dinasti. Kompas, Februari.

Hidayat, Syarif. 2007. "Shadow State? Bisnis dan Politik di Provinsi Banten." dalam H.S Nordholt dan G.v. Klinken (Eds.). Politik Lokal di Indonesia. Jakarta: Yayasan Obor Indonesia.

Hoogerwerf. 1985. Politikologi. Jakarta: Erlangga.

Ijsseling, S. 1979. "Hermeneutics and Textuality; Questions Concerning Phenomenology." Dalam J. Sallis (ed). Studies in Phenomenology and the Human Sciences. Atlantic Highlands, NJ: Humanities Press.

Karomah, Atu. 2008. Jawara dan Budaya Kekerasan di Banten. Al-Qalam.

Kartini, Kartono. 1986. Pengantar Metodologi Riset Sosial. Bandung: Alumni.

Kreuzer, Peter. 2005. Political Clans and Violence in The Southern Philippines. Frankfurt: PRIF.

Lontaan, Voucke. 2012. Pemilu Kada Minahasa Jadi Pertarungan Dinasti Politik Lokal. Media Indonesia, 20 September. Diakses 9 Desember 2012 (http:// www.mediaindonesia.com/ read/2012/09/20/349746/290/101/PemiluKada-Minahasa-Jadi-Pertarungan- Dinasti-Politik-Lokal).

Maran, Rafael Roga. 2001. Pengantar Sosiologi Politik. Jakarta: Rineka Cipta.

McCoy, A. 1994. An Anarchy of Families: State and Family in The Philippines. Quezon City: Ateneo de Manila University Press.

Meitzner, Marcus. 2009. Indonesia's 2009 Elections: Populism, Dynasties and the Consolidation of the Party System. Analysis, May 2009.

Miles, M.B. dan Huberman, A.M. Analisis Data Kualitatif. Jakarta: UI-Press.

Nasir, Muhammad Abdun, dkk., 2006. "Polarisasi Thariqat QadhariyahNaqsyabandiyah Lombok Pada Pemilu 2004”, Jurnal Istiqro', Vol. 05, No.01.

Nur, Muhammad, dkk. 2004. Visi Kebangsaan Religius: Refleksi Pemikiran dan Perjuangan Tuan Guru Kyai Haji Muhammad Zainuddin Abdul Madjid 1904-1997. Cet. 1. Jakarta: Logos Wacana Ilmu.

Park, Tong-Hee. 2009. "The Influence of Familism and Interpersonal Trusts of Korean Public Officials". International Review of Public Administration.

Pramono, Sidik. 2012. Konsolidasi Demokrasi Sulawesi Selatan. Kompas, Agustus.

Purwanto, Anhar. 2014. Politik Dinasti Vs Politik Multikultural. Indonesia Corruption Watch dalam Kompasiana. 21 Januari 2014.

Purwanto, Antonius. 2012. Konsolidasi Demokrasi Sulawaesi Utara. Kompas, Maret.

Rush, Michael dan Althoff, Phillip. 1997. Pengantar Sosiologi Politik. Kartini Kartono (Penj.) Jakarta: Raja Grafindo Persada.

Salim, Peter, dan Salim, Yenny. 1990. Kamus Bahasa Indonesia Kontemporer. Jakarta: Modern English Press.

Sanders, David. dalam Theory and Methods in Political Sciene. David Marsh and 


\section{Gerry Stoker (Eds.)}

Sastoatmojo, Sudijono. 1995. Perilaku Politik. Semarang: IKIP Semarang Press.

Sidel, John. 2005. "Bosisme dan Demokrasi di Filipina, Thailand dan Indonesia.” dalam John Hariss (Ed.). Politisasi Demokrasi Politik Lokal Baru. Jakarta: Demos.

Soelaiman, Munandar. 1998. Dinamika Masyarakat Transisi. Yogyakarta: Pustaka Pelajar.

Subagyo, Joko P. 1997. Metode Penelitian dalam Teori dan Praktek. Jakarta: Rieneka Cipta.

Suprapto. 2006. "Pesantren dan Pemberdayaan Masyarakat: Menimbang Aktivitas

Dakwah bi al-Hal Pesantren di Lombok”. Jurnal Tasamuh, Vol. 4, Nomor 1, Desember.

Querubin, Pablo. 2010. Family and Politics: Dynastic Persistence in The Philippines. Cambridge: Harvard \& MIT Academy.

Zulkarnain. 2008. Tuan Guru Bajang Berpolitik dengan Dakwah dan Berdakwah dengan Politik: Menata Pluralitas di Balik Tabir politik. Pare Kediri: Kaysa Madia.

Zuhro, Siti, et al. 2010. Demokrasi Lokal. Yogyakarta: Penerbit Ombak. 